\title{
Latihan Fisik Intesitas Submaksimal dan Kalsitonin Salmon Meningkatkan Kepadatan Tulang Tikus Masa Pertumbuhan
}

\author{
Submaximal- Intensity Exercise and Salmon Calcitonin Improve Bone \\ Density In Growing Rat
}

\author{
Heru S Lesmana ${ }^{1}$, Gadis M Sari ${ }^{2}$, Choesnan Effendi ${ }^{2}$, Shinta Arisanti ${ }^{1}$ \\ ${ }^{1)}$ Pascasarjana Ilmu Kesehatan Olahraga, ${ }^{2}$ Departemen Ilmu Faal \\ Fakultas Kedokteran Universitas Airlangga \\ Kampus A Jl. Mayjen Prof. Dr. Moestopo 47 Surabaya \\ Email: herulesmana04@gmail.com
}

\begin{abstract}
Bone is a complex tissue consisting of cells and matrix. Mass and thick bone mass has a dynamic addition and subtraction through the process of remodeling (bone matrix absorbed and formed again). Bone is formatted by osteoblast cell and resorption by osteoclast cell. Osteoblasts produce a matrix of osteoid, which is composed mainly of type I collagen, and osteoclast removes bone tissue by removing its mineralized matrix and breaking up the organic bone. Bone remodeling purpose to defend shape and structure of bone. the purpose of this study is to prove that submaximal-intensity exercise and salmon calcitonin improve bone density in growing rat this research method uses design of the randomize posttest only control group design. We compered femur bone density in 24 male norvegicus rats aged 6 weeks that were divided into 4 groups: controls, calcitonin, exercise, combine. Exercise group swam 3 times a week in submaximal intensity, calcitonin group injected synthetic salmon calcitonin 2 iu /100 gram of rat weight every day and combine group did both of it. After 8 weeks, rat femur bone density measured using ultrasound. the result: there are significant differences in bone density between group 1 (control) and group 4 (combine) with $p=0.001$, thus the $p$ value $<0.05$ indicates that there is a significant difference to the average density in both groups. While comparisons to other groups found no significant difference because the value of $p>0.05$. the benefits of this research are calcitonin salmon and submaximal-intensity exercise increase the density bone in the growth period. High bone density is mean the bone is strong and health, not porous and fragile so decrease bone fracture risk. increase the bone density in of growth period make the bone get the best mass, and avoid from early osteoporosis.
\end{abstract}

Keywords: Calcitonin salmon, Submaximal-intensity exercise, Bone density

\section{PENDAHULUAN}

Tulang merupakan jaringan kompleks yang terdiri atas sel dan matriks. Matriks tulang dibentuk oleh serat-serat dan subtansi dasar yang mengandung garamgaram mineral. Massa dan tebal tulang setiap saat selalu mengalami dinamika penambahan dan pengurangan melalui proses remodeling (matriks tulang diserap dan dibentuk lagi). Remodeling bertujuan agar tulang dapat mempertahankan bentuk dan strukturnya. Sel yang berperan membentuk tulang adalah osteoblas dan sel yang berperan menyerap tulang adalah osteoklas. Osteoblas normal mampu meletakkan kolagen tipe I dan membentuk 
tulang baru, sedangkan osteoklas mengikis dan menyerap tulang yang sudah terbentuk.Adanya proses pembentukan dan penyerapan tulang tersebut maka perlu upaya untuk menjaga kepadatan tulang sejak usia dini. Memiliki massa tulang yang tinggi berarti tulang kuat dan sehat sehingga tidak mudah kropos dan rapuh sehingga terhindar dari osteoporosis dini (Junqueira, 2007; Ganong, 2008).

Osteoporosis adalah salah satu bentuk kelainan pada tulang yang ditandai dengan menurunnya massa tulang secara keseluruhan disertai dengan rusaknya arsitektur tulang yang berakibat menurunnya kekuatan tulang. Di Indonesia jumlah penderita osteoporosis terus meningkat. Hal tersebut dapat dilihat dengan semakin tingginya kenaikan insiden patah tulang paha atas akibat osteoporosis pada 2007-2010, dari sekitar 20 ribu kasus pada 2007 meningkat menjadi sekitar 43 ribu kasus pada 2010 (Depkes, 2010). WHO mendata sekitar 200 juta orang menderita patah tulang pinggul akibat osteoporosis di seluruh dunia (WHO,2012).

Salah satu upaya yang bisa dilakukan untuk meningkatkan ketebalan tulang epifisis dan kepadatan tulang adalah dengan latihan fisik. Dari beberapa penelitian didapati latihan fisik yang dilakukan secara teratur dan dengan dosis tertentu menyebabkan peningkatan pada kepadatan tulang, ukuran tulang dan bentuk tulang (Ide, 2012). Latihan fisik merupakan salah satu stressor fisik yang dapat mempengaruhi komposisi tulang. Latihan fisik merupakan aktivitas fisik yang berulang dan bertujuan untuk memelihara, meningkatkan dan mengekspresikan kebugaran. Latihan fisik sangat bermacammacam jenisnya seperti jalan cepat, jogging, bersepeda, berenang dan semua jenis senam (Bompa, 1994).

Dalam latihan fisik terdapat komponen latihan yang terdiri dari dosis latihan (durasi, jarak dan jumlah repetisi), intensitas (beban dan kecepatan) dan frekuensi latihan. Intensitas latihan menunjukan komponen kualitatif performa kerja yang dilakukan selama latihan waktu tertentu. Derajat intensitas dapat diukur berdasarkan tipe olahraga (Bompa, 1994). Intensitas submaksimal merupakan intensitas yang tingkat pembebanannya antara sedang dan tinggi. Latihan fisik intensitas submaksimal merupakan latihan fisik yang hampir mendekati intensitas tinggi. Latihan intensitas submaksimal menyebabkan perubahan pada sistem kardiovaskuler seperti peningkatan stoke volume, penurunan Heart rate, dan sedikit penurunan pada cardiac output (Fox, 1993). Namun pengaruh latihan fisik intensitas submaksimal terhadap ketebalan lempeng epifisi dan kepadatan tulang masih belum jelas.

Ada beberapa hormon yang dapat mempengaruhi jaringan tulang antara lain kalsitonin, paratiroid, hormon pertumbuhan (growth hormone), androgen dan estrogen (Junqueira, 2007). Kalsitonin adalah hormon polipeptida yang berperan dalam menurunkan kalsium plasma. Dalam perkembangannya diciptakan sintetis atau rekombinan dari spesies yang berbeda yaitu babi kalsitonin, belut kalsitonin dan salmon kalsitonin yang telah digunakan untuk tujuan medis. Salmon kalsitonin sejauh ini yang sering digunakan dalam praktek klinis karena 40-50 kali lebih tinggi potensi intrinsik bila dibandingkan dengan kalsitonin manusia, dan sifat analgesiknya yang lebih baik (Ganong, 2008). Pada manusia kalsitonin biasanya digunakan untuk mengobati penyakit pascamenopaus,osteoporosis, penyakit tulang paget, dan hiperkalsemia. Peranan kalsitonin salmon dalam fisiologi tulang normal manusia masih belum dipahami secara jelas (Novartis, 2009). 
Tujuan penelitian ini untuk mengetahui potensi kalsitonin salmon dan latihan fisik dalam meningkatkan kapadatan tulang, dari hasil penelitian diharapakan dapat menajdi alternatif upaya pencegahan osteoporosis dini sehingga angka kejadian osteoporosis di Indonesia dapat berkurang.

\section{MATERI DAN METODE}

Penelitian yang dilakukan adalah penelitian ekperimental dengan menggunakan rancangan The postest-Only Control Group Design

Sampel penelitian adalah tikus putih (rattus norvegicus) jantan masa pertumbuhan dengan berat badan $160-180$ gram, umur $6-8$ minggu, kondisi sehat fisik, yang didapat dari unit pengembangan hewan penelitian Laboratorium Biokimia Fakultas Kedokteran Universitas Airlangga. Teknik pengambilan sampel dalam penelitian ini dilakukan dengan cara simple random sampling. Tikus sebanyak 24 ekor dibagi secara acak kedalam 4 kelompok, sehingga masing-masing kelompok beranggotakan 6 ekor tikus yaitu kelompok 1 (kontrol), kelompok 2 (pemberian kalsitonin salmon), kelompok 3 (latihan fisik intensitas submaksimal), dan kelompok 4 (kalsitonin salmon dan latihan fisik intensitas submaksimal).

Alat-alat yang digunakan dalam penelitian ini adalah Ultrasound DBM Sonic 1200 (Digital Bone Measurement Emsor, S.A, Madrid, Spain), timbangan torbal, ember untuk renang dengan diameter $50 \mathrm{~cm}$, tinggi $60 \mathrm{~cm}$ dengan kedalaman air $40 \mathrm{~cm}$, suhu air $30-36^{0} \mathrm{C}$, stopwatch untuk menghitung lama waktu renang, suntikan. Bahan-bahan yang digunakan dalam penelitian ini adalah Ketamine HCL, preparat kalsitonin salmon, K-Y lubricatting jelly.

Pemberian kalsitonin salmon yang didapat dari preparat Miacalcin yang berbentuk larutan dengan dosis 2UI/ 100 gr
BB tikus/hari pada hewan coba kelompok 1 dan 3, diberikan dengan cara disuntikan per subkutan 1 kali sehari, selama 8 minggu diberikan pada pagi hari dan untuk kelompok 3 diberikan setelah latihan fisik. Perhitungan dosis berdasarkan penelitian terdahulu (Khaldi et al, 2005).

Pemberian latihan fisik intensitas submaksimal dengan cara menghitung waktu maksimal kemampuan renang terlebih dahulu. Waktu maksimal didapat dengan cara tiap tikus berenang sampai tenggelamnya tikus yang ditandai keluarnya gelembung udara besar pertama kali. Waktu latihan tiap tikus diambil $85 \%$ dari waktu maksimal yang dicapai oleh masing-masing tikus. Latihan diberikan 1 kali sehari, dengan frekuensi 3 kali seminggu pada hari senin, rabu dan jum'at selama 8 minggu (Bompa, 1994; Kragel et al, 2006; Coutinho et all, 2011). Setelah perlakuan selama 8 minggu kepadatan tulang tikus diukur dengan menggunakan Ultrasound DBM Sonic 1200 dengan satuan pengukuran $\mathrm{m} /$ detik, yang diukur adalah tulang metafisis femur. Perlakuan penelitian dilakukan selama 8 minggu berdasarkan waktu yang diperlukan osteoblas untuk mengisi kavitas yang diresorpsi (Raisz, 1988 cit Sunoto, 2001). Penelitian dilakukan di Unit Hewan Coba Laboratorium Ilmu Biokimia Fakultas Kedokteran Universitas Airlangga.

Data yang diperoleh ditabulasi dan dianalisis secara statistik melalui tahapan dilakukan uji normalitas data dengan OneSample Kolmogorov-Smirnov Test, uji homogenitas variansi dengan menggunakan Anova, dengan syarat data berdistribusi normal dengan variansi homogen, jika didapatkan hasil analisis $\mathrm{H}_{0}$ ditolak, maka dilanjutkan dengan uji Least Significant Difference (LSD) untuk mengetahui beda antar perlakuan. 


\section{HASIL DAN PEMBAHASAN}

Tabel 1.hasil rata-rata kepadatan tulang dan berat tulang

\begin{tabular}{ccc}
\hline Kelompok & Kepadatan tulang $(\mathrm{m} / \mathrm{s})$ & Berat tulang $(\mathrm{g})$ \\
\hline Kontrol & 1572,14 & 0,52 \\
Kalsitonin & 1618,29 & 0,60 \\
Latihan fisik & 1625,14 & 0,66 \\
Kombinasi & 1701,57 & 0,7 \\
\hline
\end{tabular}

Berdasarkan pada table di atas, hasil penelitian dapat digambarkan dalam bentuk grafik sebagai berikut:

Grafik 1. hasil rata-rata berat tulang

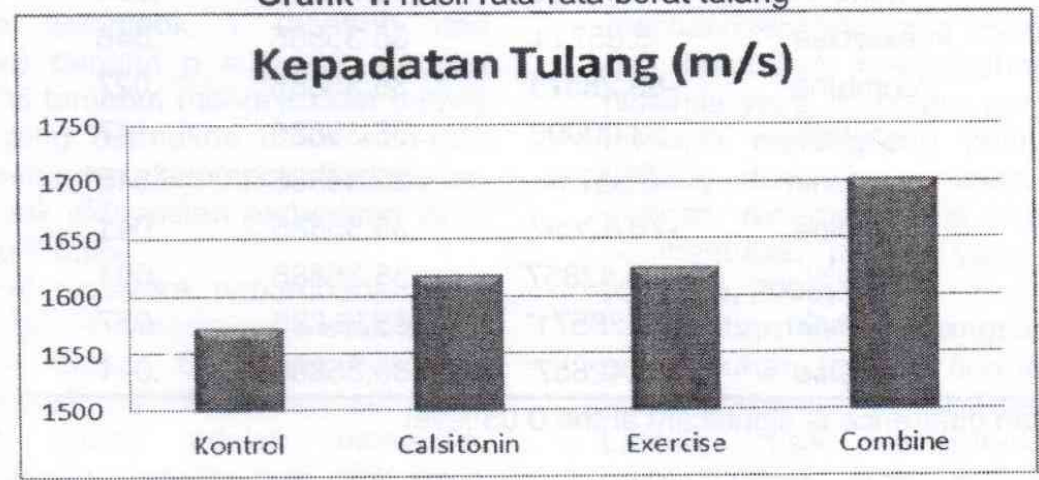

Grafik 2. hasil rata-rata berat tulang

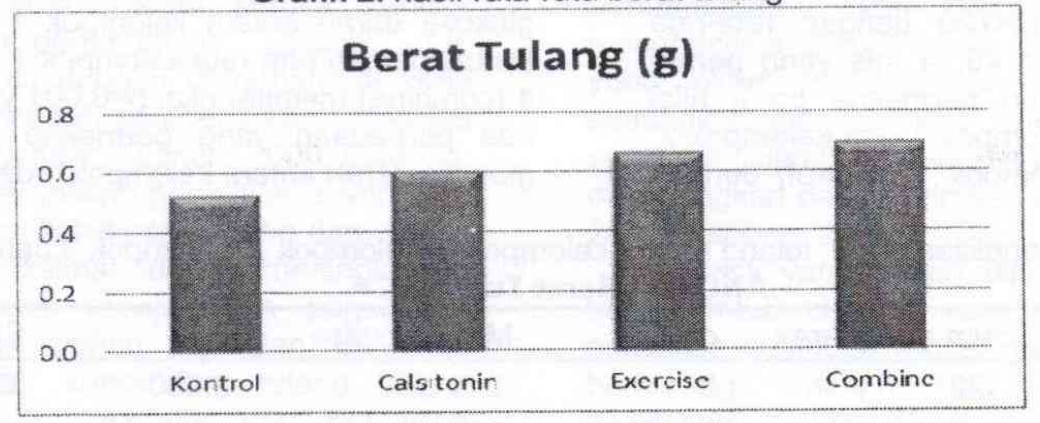

Data selanjutnya dianalisis dengan menggunakan software SPSS17, dari hasil analisis didapatkan hasil sebagai berikut:

Tabel 2. Hasil one way anova kepadatatan tulang

ANOVA Densitas

\begin{tabular}{lccccc}
\hline & Sum of Squares & df & Mean Square & $F$ & Sig. \\
\hline Between Groups & 60400.857 & 3 & 20133.619 & 4.601 & .011 \\
Within Groups & 105020.857 & 24 & 4375.869 & & \\
Total & 165421.714 & 27 & & & \\
\hline
\end{tabular}


Hasil uji One Way Anova menunjukan bahwa kepadatan tulang memiliki nilai $\mathrm{p}=0,01$ $(\alpha=0,05)$. Nilai $p<0,05$ tersebut menunjukan bahwa terdapat perbedaan yang bermakna untuk rata-rata kepadatan tulang pada seluruh kelompok.

Tabel 2. Hasil uji Perbandingan rata-rata kelompok perlakuan dengan Post Hock Test-LSD

\begin{tabular}{|c|c|c|c|c|}
\hline \multicolumn{5}{|c|}{ Multiple Comparisons - Densitas LSD } \\
\hline (I) Kel & (J) Kel & $\begin{array}{c}\text { Mean Difference } \\
(I-J)\end{array}$ & Std. Error & Sig. \\
\hline \multirow[t]{3}{*}{ kontrol } & calcitonin & -46.14286 & 35.35885 & .204 \\
\hline & exercise & -53.00000 & 35.35885 & .147 \\
\hline & combine & $-129.42857^{*}$ & 35.35885 & .001 \\
\hline \multirow[t]{3}{*}{ calcitonin } & kontrol & 46.14286 & 35.35885 & .204 \\
\hline & exercise & -6.85714 & 35.35885 & .848 \\
\hline & combine & $-83.28571^{*}$ & 35.35885 & .027 \\
\hline \multirow[t]{3}{*}{ exercise } & kontrol & 53.00000 & 35.35885 & .147 \\
\hline & calcitonin & 6.85714 & 35.35885 & .848 \\
\hline & combine & $-76.42857^{*}$ & 35.35885 & .041 \\
\hline \multirow[t]{3}{*}{ combine } & kontrol & $129.42857^{*}$ & 35.35885 & .001 \\
\hline & calcitonin & $83.28571^{*}$ & 35.35885 & .027 \\
\hline & exercise & $76.42857^{*}$ & 35.35885 & .041 \\
\hline
\end{tabular}

Hasil uji LSD (perbandingan rata-rata) kepadatan tulang antara kelompok 1 (kontrol) dengan kelompok 2 (calcitonin) memiliki nilai $\mathrm{p}=0,20$ dengan rata-rata perbedaan kapadatan tulang $46,14 \mathrm{~m} / \mathrm{s}$ yang berarti bahwa tidak ada perbedaan bermakna pada nilai kepadatan tulang antara kelompok 1 dan kelompok 2 . Perbandingan rata-rata kelompok 1 (kontrol) dengan kelompok 3 (exercise) memiliki nilai $\mathrm{p}=0,147$ yang berarti bahwa tidak ada perbedaan pada nilai kepadatan tulang antara kelompok 1 dan kelompok 3. Perbandingan rata-rata kelompok 1 dengan kelompok 4 (combine) memiliki nilai $\mathrm{p}=0,001$ yang berarti ada perbedaan bermakna pada nilai kepadatan tulang antara kelompok 1 dan kelompok 4 .

Tabel. 4. Hasil One way Anova berat tulang

\begin{tabular}{llllll}
\hline \multicolumn{7}{c}{ ANOVA - Berat Tulang } \\
\hline & Sum of Squares & df & Mean Square & F & Sig. \\
\hline Between Groups & .122 & 3 & .041 & 3.530 & .030 \\
Within Groups & .277 & 24 & .012 & & \\
Total & .399 & 27 & & & \\
\hline
\end{tabular}

Hasil uji statistic One Way Anova menunjukan bahwa kepadatan tulang memiliki nilai $p=0,03(\alpha=0,05)$. Nilai $p<0,05$ tersebut menunjukan bahwa terdapat perbedaan yang bermakna untuk rata-rata berat tulang pada keseluruhan kelompok. 
Multiple Comparisons - Berat Tulang LSD

\begin{tabular}{lllll}
\hline \multirow{2}{*}{ (I) Kel } & \multicolumn{1}{c}{$(\mathrm{J})$ Kel } & $\begin{array}{c}\text { Mean Difference } \\
(\mathrm{I}-\mathrm{J})\end{array}$ & Std. Error & Sig. \\
\hline kontrol & calcitonin & -.08143 & .05742 & .169 \\
& exercise & $-.14000^{*}$ & .05742 & .023 \\
& combine & $-.17429^{*}$ & .05742 & .006 \\
calcitonin & kontrol & .08143 & .05742 & .169 \\
& exercise & -.05857 & .05742 & .318 \\
& combine & -.09286 & .05742 & .119 \\
exercise & kontrol & $.14000^{*}$ & .05742 & .023 \\
& calcitonin & .05857 & .05742 & .318 \\
& combine & -.03429 & .05742 & .556 \\
combine & kontrol & $.17429^{*}$ & .05742 & .006 \\
& calcitonin & .09286 & .05742 & .119 \\
& exercise & .03429 & .05742 & .556 \\
\hline
\end{tabular}

${ }^{*}$. The mean difference is significant at the 0.05 level.

Hasil uji LSD pada berat tulang menunjukan perbedaan yang bermakna terdapat pada perbandingan antara kelompok 1 (kontrol) dan kelompok 4 (combine) dengan $\mathrm{p}=0,006$ dengan demikian nilai $\mathrm{p}<0,05$ tersebut menunjukan bahwa terdapat perbedaan yang bermakna untuk rata-rata berat tulang pada kelompok 1 denga kelompok 4. Sedangkan pada kelompok lain tidak terdapat perbedaan yang bermakna karena nilai $p>0,05$.

Tulang mengalami dinamika penambahan dan pengurangan melalui proses remodeling (matrik tulang diserap dan dibentuk lagi). Sel yang berperan membentuk tulang adalah osteoblas dan sel yang berperan menyerap tulang adalah osteoklas (Ganong, 2008). Kalsitonin rnemiliki dua efek pada tulang dan dapat mengakibatkan penurunan kadar kalsium plasma. Pertama dalarn jangka pendek kalsitonin menurunkan perpindahan kalsium dari tulang ke dalam plasma dengan menghambat kerja osteoklas. Kedua mencegah pernbentukan osteoldas baru dari sel osteoprogenitor (Guyton, 2006; Ganong,2008). Penelitian ini merupakan penelitian dasar yang membuktikan pemberian kalsitonin salmon dan latihan fisik intensitas submaksimal dapat rneningkatkan kepadatan tulang. Untuk menjelaskan bagaimana rnekanisme bagaimana latihan fisik dan kalsitonin salmon mernpengaruhi kepadatan tulang dapat mengacu pada beberapa literatur dan penelitian sebelumnya. Latihan fisik mendorong perubahan dalam metabolisme tulang melalui efek langsung dan tidak langsung, efek langsung rnelalui kekuatan mekanik (mechanicforce) sedangkan tidak langsung melalui faktor hormonal. Kekuatan mekanik bila diterapkan dalam jaringan tulang membentuk tanda endogen. Tanda-tanda tersebut ditangkap oleh sistem mechanosensoric yang akan ditangkap oleh osteosit dan kemudian mengubahnya menjadi tanda-tanda biokimia yang mengatur pergantian tulang. Kekuatan mekanik merangsang pelepasan prostaglandin E2 (PGE2) dari gap junction. 
PGE2 akan berikatan dengan reseptor pada osteosit dan merangsang pembentukan protein yang menjadi matriks tulang (Ocarino, 2006).

Latihan fisik merangsang sekresi dari hormon pertumbuhan (growth hormone), salah satu honnon yang berperan dalam masa pertumbuhan tulang. Latihan fisik intensitas submaksimal akan menyebabkan stressor yang akan merangsang hipofisis anterior mensekresi growth hormone. Hormon pertumbuhan akan merangsang hati untuk rnenghasilkan Insulin- Like Growth Factor - 1 (IGF-1) yang akan meningkatkan kinerja sel osteoblas, sedangkan sel osteoklas kinerjanya akan menurun, sehingga pembentukan tulang akan lebih tinggi dibandingkan dengan proses resorpsi tulang (Guyton,2006; Ganong, 2008).

Seperti yang sudah dijelaskan kalsitooin dapat menghambat aktivitas osteoklas dan pembentukan osteoklas sehingga proses penyerapan tulang dapat berkurang. Latihan fisik dengan skema yang dijelaskan diatas dapat meningkatkankan kinerja osteoblas yang dapat berperan dalam proses pembentukan tulang. Dengan meningkatnya kinerja osteoblas maka proses mineralisasi tulang dapat meningkat sernentara itu penurunan kinerja osteoklas menyebabkan penyerapan tulang yang telah terbentuk menjadi berkurang sehingga akan meningkatkan kepadatan tulang.

Penelitian ini bertujuan untuk membuktikan pemberian kalsitonin salmon dan latihan fisik secara akan meningkatkan kepadatan tulang pada saat masa pertumbuhan. Memiliki massa tulang yang tinggi berarti tulang kuat dan sehat sehingga tidak mudah kropos dan rapuh. Meningkatkan kepadatan tulang dimasa pertumbuhan diharapkan kepadatan tulang akan optimal ketika masa pertumbuhan berakhir sehingga terhindar dari osteoporosis dini.

\section{KESIMPULAN}

Pemberian kalsitonin salmon dan latihan fisik submasimal dapat meningkatkan kepadatan tulang. Kombinasi pemberian kalsitonin salmon dan latihan fisik intensitas submaksimal lebih meningkatkan kepadatan tulang dibanding dengan pemberian kalsitonin saja atau latihan fisik intensitas sumaksimal saja.

\section{DAFTAR PUSTAKA}

Bompa TO, 1994. Theory and metodology of training, the key to athletic performance $3^{\text {rd }}$ ed. Lowa: Hunt Publising Company, pp 24-26.

Borer, Katerina, 2005. Physical activity in the prevention and amelioration of osteoporosis in women. Sports Med. 35 (9): 779-830.

Burn EF. 1999. Anatomy and physiology. USA: Hill companies, pp 19,20.

Carola R. 1992. Human anatomy. USA: Hill Companies, pp 129, 133, 132.

Fox EL. 1993. The physiological basis exercise and sport $5^{\text {th }} e d$. USA: MW. Crown Communication, pp 287-289, 430-436, 514.

Ganong WF, 2008. Review of medical physiology $22^{\text {th }}$ ed.USA: Appleton \& lange.

Graff VD, Kent M. 1998. Human anatomy $5^{\text {th }}$ ed. USA: Hill Companies, pp 131, 133, 134, 137.

Guyton AC, Hall JE. 2006. Textbook of medical physiology $11^{\text {th }} \mathrm{ed}$. Philadelphia: Elsevier Inc, pp 987-990.

Ide P. 2012. Agar tulang sehat. Jakarta: PT Elex Media Komputindo., Hlm 4 - 5.

Junqueira LC, Carneiro J. 2007. Basic histology: text and atlas $10^{\text {th }} \mathrm{ed}$. California: Hill Companies, pp 135137, 145.

Khaldi L, Th.Karachal ios, Galanos A, Lyritis GP. 2005. "Morphometric 
changes in the epiphyseal plate of the growing and young adult male rat after long-term salmon calcitonin administration". Calcif Tissue Int. 76:426-432.

Lesson CR, Lesson TS, Paparo A, 1996. Buku ajar histologi dasar. Jakarta: EGC.

Naot D and Cornish J, 2008. The role of peptides and receptors of the calcitonin family in the regulation of bone metabolism. Elsevier. 43: 813-818.

Novartis, 2009. Miacalcin. New Jersey: Novartis Pharmaceuticals Corporation.

Ocarino NM, Serakides R, 2006. Effect of the physical activity on normal bone andon the osteoporosis prevention and treatment. Rev Bras Med Esporte. 12: $149-152$.

Sari GM, 2001. Pengaruh pemberian ekstrak kedelai (glycine max) dibanding estrogen konjungsi terhadap kepadatan tulang tikus putih (rattus norvegicus). Tesis, Program Pascasarjana, Universitas Airlangga, Surabaya, pp 2,13-17.
Thibodeau, 1994. Structure and funcition of the body $15^{\text {th }}$ ed. USA: Mosby Year Book, pp 79-84.

Tjokroprawiro A, 2000. Introduction with osteoporosis. Naskah Symposium on Osteoporosis, FK UNAIR. Surabaya hlm 1-10.

Turner CH, Robling AG. 2005. "Exercise for improving bone strength". $\mathrm{Br} J$ Sport Med. 39:188-189.

Vigorita VJ, Ghelman B. 1999. Othopaedic pathology. Philadelphia: Lippicott Williams and Wilkin, pp 1019.

Zaidi M, Moonga BS and Abe E. 2002. "Calcitonin and bone formation: a knockout full of surprises". J. Clin. Invest. 110:1769-1771.

Zainudin M. 2000. Bahan ajar metodologi penelitian. Surabaya: Universitas Airlangga. 
MAJALAH ILMU FAAL INIDONESIA

The Indonesian Journal of Physiology

VOLUME 11 NOMOR 1, MARET 2014

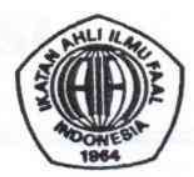

Majalah IImu Faal Indonesia memuat tulisan ilmiah yang terkait dengan bidang fisiologi .

Tertit setiap 4 bulan, berdasarkan SK Ketua Umum Pengurus Pusat Ikatan Ahli IImu Faal Indonesia No. 001/SK/IAIFI/IX/2000, taniggal 14 September 2000

\title{
Susuman Dewan Redaksi
}

\author{
Ketua Penyunting \\ Purwo Sri Rejeki \\ Sekretaris \\ Sundari Indah Wiyasihati \\ Bendahara \\ Ratna Damayanti \\ Iklan dan Langganan \\ Yuliati \\ Penyunting Pelaksana \\ Lilik Herawati \\ Raden Argarini \\ Aqsa Sjuhada \\ Irfiansyah Irwadi \\ Penyunting Teknik \\ Kuncoro Puguh Santoso \\ Tata Usaha \\ Muhammad Taufik Kurniadi
}

\begin{abstract}
Alamat : Departemen Faal Fakultas Kedokteran Universitas Airlangga Jl. Mayjen. Prof. Dr. Moestopo 47 Surabaya 60132

Telp: (031) 5023621 Fax: (031) 5023621 Email: workshop.mifi@yahoo.com

Rekening : Ratna Damayanti, drh., M.Kes

Bank NIAGA IBC Dharmahusada Surabaya No. 033-01-11506-13-2
\end{abstract}

MAUALAH ILMU FAAL INDONESIA diterbitkan oleh Ikatan Ahli Ilmu Faal Indonesia (IAIFI) Harga berlangganan : Rp. $50.000,00$ per nomor 


\section{MAJALAH ILMU FAAL INIDONESIA}

\section{The Indonesian Journal of Physiology}

VOLUME 11 NOMOR 1, MARET 2014

\section{DAFTAR IS}

\section{DAFTAR ISI}

Pemberian Jus Bayam Merah (Amaranthus tricolor) pada Induk Mencit Bunting yang Terpapar Timbal Asetat Meningkatkan Kemampuan Belajar dan Memori Anak Mencit (Mus musculus) Pascasapih

Made Puri Pratiwi, Noer Halimatus Syakdiyah, Etha Dini Widiasi, Mayang Rizki Anggraeni, Intan Anggun Pratiwi, Viskasari Pintoko Kalanjati, Raden Argarini

Pengaruh Latihan Aerobik dan Pemberian Rebusan Kulit Manggis Terhadap Kadar Adiponektin pada Tikus Putih (Rattus Norvegicus Wistar) Jantan

Muhammad Danial, Elyana Asnar, Harjanto

Resting Heart Rate and Body Weight is Diskriminator of Fitness Status in Physical Activity Weight Bearing Exercise

Bayu Agung Pramono, Shinta Arisanti, Harlina, Elyana Asnar

Curcumin Menghambat Karbonilasi Protein Lensa pada Model Tikus Diabetes yang Diinduksi Streptozotocin Wulandari Meilia, Dewi Masyithoh Budi, Setiowati Ditya Ayu Intan, Hayuningtyas Duhita Pramesthi, Fauzia Kartika Afrida, Bambang Purwanto

Latihan Fisik Intensitas Submaksimal dan Kalsitonin Salmon Meningkatkan Kepadatan Tulang Tikus Masa Pertumbuhan

Heru Syarli Lesmana, Choesnan Effendi, Gadis Meinar Sari

Pengaruh Kebugaran Jasmani, AktifitasFisik, dan Indeks Massa Tubuh terhadap Indeks Prestasi Kumulatif (IPK) Mahasiswa Kedokteran Universitas Malahayati Bandar Lampung Ringgo Alfarisi

Pengaruh Pemberian Jus Pisang Raja Terhadap Kinerja Olahraga Yesticia Erwinda Josef, Hayati

Pengaruh Sarapan Terhadap Tingkat Konsentrasi Belajar di Pagi Hari pada Siswa SMAK Santo Stanislaus Surabaya

Birgitta Suparman, Raden Argarini, Widati Fatmaningrum

Aktivitas Eksentrik Dinamik Memperbaiki Ambilan Glukosa Total pada Model Mencit Diabetes Havid Yusuf, Soedarso Djojonegoro, Tjitra Wardani

Kualitas Spermatozoa Kauda Epididimis Domba Masa Tumbuh yang Diberi Ekstrak Etanol Daun Katuk pada Penyimpanan $4^{\circ} \mathrm{C}$

Arum Saksono, M. Agus Setiadi, Agik Suprayogi 